\title{
Narnia: An Affirmative Vision
}

\author{
Pat Pinsent
}

$\mathrm{O}$ pinions about the work of C.S. Lewis, and in articular his Narnia books, have often been polarised. Comments from published interviews with two of the best-selling contemporary writers for young people reflect this divide:

Lewis is simply a genius. Even now, if I was in a room with one of the Narnia books / would pick it up like a shot and re-read it.

(Joanne Rowling, in The Guardian, June 1999).

The Narnia books lead up to a view of life so hideous and cruel I can scarcely contain myself when I think of it.

(Philip Pullman, as quoted in The Times, October 2000)

The strength with which contrasting opinions about Lewis are expressed is especially notable. On the one hand. for many years. especially in America, he seems to have been regarded as an uncanonised saint, whose every word. particularly in his explicitly religious works, is to be treated with reverence. On the other, nearly 30 years ago. the renowned educationalist. David Holbrook, suggested that. Under cover of his apparent religious intentions and his mask of benignity C.S.Lewis conveys to his readers a powerful unconscious message that the world is full of malignancy ... that aggression is glorious, exciting and fully justified; that tenderness, cowardice and reticence are weak' (1973, in Fox 1976, p. 124). The response of Walter Hooper (1974) to Holbrook's polemic is at least as forthright: "The Narnian books are suffused throughout with moral teaching of a quality which I don't believe anyone. whatever his beliefs, could fairly object to...

The Last Batlle, the final book of the Narnia series. has perhaps attracted the most controversy: Hooper (1974) says, "The Last Batlle is...the best-written and most sublime of all the Narnian stories', while Pullman, who sees the books 'as little more than Christian propaganda, life-denying rather than life-affirming', cites particularly the end of The Last Batle where the children are "'rewarded", or so it stems. by death' (Pullman. The Times, October 2000).

My intention is not to justify Lewis's views. so characteristic of his culture and period, about the moral value of a 'iust war' and 'fighting the good fight'. Nor shall I attempt to excuse his outrageous treatment in banishing Susan from Aslan's kingdom, though I shall examine possible reasons for Lewis's hostility to her development of normal feminine interests and the trappings of adolescence. I propose to concentrate rather on the positive aspects of Lewis's work: the life-enhancing qualities of his writing, and the kind of spirituality which his books propose. I will claim that Lewis's implicit ideology (cf. Hollindale, quoted in Stephens 1992, pp.811) often contradicts, or at least problematises, his explicit glorification of masculinity. As we are reminded by Lissa Paul (1998, p.11). 'Acknowledging and valuing multiple interpretations, or variable interpretations, is a critica! attitude that has come to be very much a part of a late twentieth-century mind-set. 'It is therefore possible to recognise that while we may have no direct access to Lewis's own intentions, other than through the context of his own clearly stated beliefs about Christianity, the books may be read in ways which are both consonant with and counter to his explicit understandings of religion and spirituality.

\section{Spirituality and the Narnia books}

My claim that the Narnia books present a largely affirmative vision will be integrally related to the way in which they present two alternative, though not always conflicting, views of spirituality. The term 'spirituality'. though much in use today, tends to lack precision; here are two contrasting definitions:

[Spirituality is] the personal assimilation of the salvific mission of Christ byeach Christian which is always in the framework of new forms of Christian conduct and is comprised within the fundamental answer of the Church to the word of salvation. (Sudbrack 1975, p.1624)

[Spirituality has] to do with an age-old quest to seek fulfilment, liberation and pointers towards transcendence amidst the welter of human experience... something which permeates all human activities and experiences rather than being additional to them... a process of transformation and growth, an organic and dynamic part of human development. (King 1989.p.5) 
There seems little doubt that Lewis would have been more at home with the first of these definitions than the second, though, as I will show, evidence of both stances is to be found, at least inplicitly, within his work. Paradoxically, in Lewis's own illumination of traditional Christian spirituality, he notably exalts the female element, though not necessarily in a way readily acceptable to Christian feminists.

\section{C.S.Lewis and female spirituality}

Central to Lewis's presentation of Christian spirituality is the character of Lucy Pevensie.

There was in fact a real Lucy, Lewis's god-daughter Lucy Barfield, to whom The Lion, the Witch and the Wardrobe is dedicated, but the character's name, derived from the Latin for light, is immensely significant and I wonder whether this fortuitously helped determine the direction of the narrative. Lucy is the first of the Pevensie children to enter Narnia, and her responses guide the reader towards an appreciation, which may not necessarily be explicit, of Aslan as a Christ figure. The children's varied reactions when they first hear about Aslan are very significant as a means of characterisation, as well as indicating Lewis's views about how to respond to spiritual experience. Peter feels brave and adventurous, Susan responds as if perceiving some delicious smell or delightful music, while Edmund, who is on the point of betrayal of his siblings, has a sensation of mysterious horror. Lucy's perception is the most appropriate to Aslan's life-giving qualities: 'Lucy got the feeling you have when you wake up in the morning and realize that it is the beginning of the holiday's or the beginning of summer' (1959a, p.65). It is surely no accident that this comparison is echoed at the end of the saga in The Last Battle when Aslan tells the children that they' will not be going back to earth but will be in his country forever: 'The term is over: the holidays have begun. The dream is ended: this is the morning.' (1964. p.165)

In this final volume, it is Lucy who understands the significance of the Stable which is the way into Aslan's country: 'In our world too, a Stable once had something inside it that was bigger than our whole world.' (1964, p.128). Elsewhere, she tries to put the other children on the right path when they are lost. In Prince Caspian, in a scene reminiscent of the biblical call of Samuel, she hears Aslan's voice (1962, p. 120) and ultimately is able to see him, long before any of the others can (1962, pp.129132).

Consistently Lucy has the closest relationship with Aslan. Although Susan is also associated with Lucy in the scenes which most closely resemble the Passion of Christ in The Lion, the Witch and the Wardrobe, (1959, pp.133-146), on all other occasions it is Lucy alone who has the warmest relationship with him; at times it is physical and verges on the erotic. At the end of The Voyage of the Dawn Treader, when Aslan tells Edmund and Lucy that they will never come back to Narnia because they are too old, she sobs: 'It isn't Narnia, you know... It's you. We shan't meet you there. And how can we live, never meeting you?' (1965a, p.209).

Lucy's obedience to Aslan is total; when the children have unexpectedly been summoned into Narnia to help Prince Caspian regain his throne, an experience which Edmund finds a little uncomfortable, Lucy says, 'We want to be here...if Aslan wants us.' (1962. p.90). She is particularly associated with truth. refusing early in The Lion, the Witch and the Wardrobe to deny that she has been to Narnia. even though her siblings make her feel very unhappy and Edmund jeers and sneers at her for maintaining this truth $(1959$, p.29). One of her most significant roles is to bring healing to others, through the power of the cordial given her by Father Christmas but ultimately deriving from Aslan himself (1959, p.100)

While it is always clear that Lucy's behaviour is entirely appropriate to her sex and gender, the fact that very often the outcome reveals that she possesses a greater wisdom than her brothers elevates her in the reader's eyes to the extent of her proving to be a paradigm for authentic Christian attitudes. rather than Peter's fairly stereotypical masculine actions.

Lucy's contrast with her sister is still more striking than that with her brothers. Susan in many respects represents the other pole of stereotypical femininity from Lucy's caring submissiveness. Even near the beginning of the Chronicles, she has a different attitude towards truth from Lucy's, believing that Edmund should be shielded from 
the unpleasant knowledge about Aslan's negotiation on his behalf with the Witch (1959, p.163). While Lucy is given the means of healing, Susan's presents (1959. p.100), though from the same source, could be seen as slightly departing from the feminine stereotype which Lewis might have advocated to young Christian readers; as well as the (somewhat strident) horn with which to summon help. she receives a bow, and arrows which she fires with outstanding accuracy in Prince Caspian (1962. p.95). The inevitable association with the goddess Diana might result in readers subconsciously sensing that Susan has a greater degree of independence than is appropriate for a female follower of Christ. By contrast, Jill Pole, who is much more positively presented than is Susan, also shoots fairly accurately, but she seems less complacent about killing than Susan does.

By the end of the Chronicles, Susan is described as no longer a friend to Narnia, because, as Jill says: 'She's interested in nothing now-a-days except nylons and lipstick and invitations. She always was a jolly sight too keen on being grown-up' (1964. p.124). Lewis's attitude to Susan is inexcusable - after all, even Edmund, the erstwhile betray'er, is allowed at the end to reach Aslan's kingdom. I suspect that many female readers feel much more positively disposed towards Susan than to Edmund or even Eustace, and are disappointed when the boys are allowed the forgiveness and acceptance which is denied to her. Perhaps the reason for this is that Edmund and Eustace are repentant sinners. Susan, who once had a closer relationship with Aslan than either of the boys achieved, has rejected it in favour of material things: this may mean that she has committed the unforgivable sin of 'blasphemy against the Holy Spirit' (Matthew 12:31).

Lucy may be regarded as stereotypical of the 'virgin' aspect of women. which in well-established Christian tradition is associated with the soul, for even a man's soul is seen as female before God. She is the means Lewis often uses to make his religious references more explicit. He seems unable to let Lucy, or even her successor in Narnia. Jill, grow up, whereas Susan 's maturation perhaps represents his fear of adult women who cannot so easily bear the weight of symbolism of virtue which can be carried by a young and innocent girl. It may be worthy of note that the Narnia books were probably completed by 1953, even though the final volume was not published until 1956. Lewis met Joy Gresham, whom he later married, in 1952, and may be presumed to have learnt a good deal about adult women as a result! Lewis's hostility to sexually mature women is of course at its most extreme in the figure of the Witch, which verges on caricature. Lucy is the visionary and healer; while these aspects are not necessarily specific to females but relate to the spiritual in general terms, they are probably for Lewis most safely symbolised by a female. The somewhat feminised Christ figure of so many of the religious paintings which Lewis will have known may remind us of how, even for men, the Christian religious ideal has often been imaged without distinctively masculine aspects.

The male characters on the other hand embody attributes often stereotypically associated with masculinity: Digory provides an intellectual voice and Peter represents fortitude. I am not implying that Lucy is merely a symbol; Lewis goes some way towards rendering her human by endowing her with 'feminine' weaknesses, the most notable of which are displayed as curiosity and vanity when she reads the spells in the magician's book in The Voyage of the Dawn Treader (1965a, pp.131-136). For these and for any lack of firm resolution (for instance, her failure to persuade her siblings about Aslan's presence in Prince Caspian. (1962, p.90), she is sternly reproved by Aslan, but in many respects she is rather too perfect to be convincing as a fully rounded character. perhaps in spite of her creator. She is not, however, passive; her insistence against all of the others that she had entered Narnia through the wardrobe when none of them, except eventually the lying Edmund, have had that experience, makes clear the resolution she possesses when she knows she is speaking the truth.

Spirituality is thus firmly associated with a female character. This obviously does not mean that men cannot be spiritual, but perhaps that in order to do so they need to abandon some of the traits associated with masculinity, for the soul has traditionally been regarded as needing to be passive before God, and females have traditionally 
been portrayed as passive. As Beverley Clack, commenting on some words of the medieval mystic Meister Eckhart. notes: "God is understood as the active masculine principle, who impregnates the passive human soul with his spirit" (1998, p.198). The obverse of this idealisation is surely the notion that a female who is not spiritual may well represent the other extreme more effectively than a male character.

Lewis's basic spirituality as explicitly expressed could be described as a kind of Christian Platonism, dependent on the Christian developing the realisation that everything on earth is a shadow of the Beauty and Truth to be found with God in heaven. In this context, there is little explicit difference between the way in which spirituality may be attained by males and females, but the latter, if they do not remove themselves from it altogether, are by nature nearer than males to the spiritual and thus to God. Lucy can be seen as typical of the soul's proper relationship to God, which is best expressed through the passivity and obedience traditionally associated with females. In so far, therefore, as a male relates to a personal God, it is through the anima (used here to mean the soul, but bearing some relationship to Jung's use of the term for the female aspect of males). It is difficult to see how the kind of warmth of physical contact which Lucy (and at one stage Susan) is portrayed as having with Aslan could easily have been presented through a male character. at least not by someone of Lewis's background. It is as if the mystical element of direct experience with God is most accessible to the female and open to the male through his female side - a well-established Christian tradition. The fulfilment of this spirituality lies in a personal relationship with Aslan. Whether deliberately or not. Lewis seems to see females as more spiritual and providing the way in which the male can become spiritual, but judging the perversion of the female to be more dangerous than the male. Lewis's explicit view portrays spirituality as a relationship with the person of Aslan/God. begun in this world and fulfilled in the next.

\section{Implicit Spirituality in the Narnia Books}

I agree with Pullman in deploring the other worldly approach of those Christians who seek for happiness only in heaven and thus devalue the things of earth, but I see no reason to suppose that Lewis was among them. If this world is not good it cannot be an adequate figure for the next. While Lewis certainly does not see this world as all that there is, he states in The Great Divorce (1945). 'Earth, if put second to Heaven [will turn out] to have been from the beginning a part of Heaven itself' (p.8). The personal experiences which led him to this belief are recounted in his partial autobiography, Surprised by Joy: The Shape of My Early Life (1959b), where he reiterates several times his realisation, even as a child, of the importance to him of a kind of longing, or 'sehnsucht', for something beyond the physical yet always stimulated by an encounter with beauty, such as that of the 'unattainable' 'Green Hills of Castlereagh' (p.12) (felt at six years old), or of the spirit of autumn (p.19) and 'northernness' (p.20) (a little later in his childhood). The physical world, as experienced through the senses, including the potentially less noble ones of smell and taste, seems always to have been important to him both in itself and in what it signified. The Narnia books abound in metonymic uses of animals and nature to represent a realm beyond the physical, a practice which no more devalues the initial signifier, than using the figure of Lucy in a symbolic way implies the diminution of her character as such.

An additional factor which reinforces my conviction about Lewis's affirmative approach to the external world is the fact that his main field of expertise in English literature was the medieval and the early Renaissance period, a period characterised by the Christian humanism of men such as Erasmus, Colet and More, and featuring Christian Platonists as notable as Ficino and Sir Philip Sidney. These men all placed a high value both on human nature and on the universe itself, while placing both in a perspective which saw everything sub specie aeternitatis. Platonic insistence on the belief that qualities giimpsed in this world as shadows of the reality elsewhere does not necessarily imply that this world is worthless; if the shadows lacked a semblance of the reality they' would be inoperative in leading humans to a perception of that reality.

It would have been impossible for Lewis to give his readers the conviction that the next world was a positive 
state to be desired without providing some kind of description of it: Lewis needs therefore to use this world to image heaven, and it is in this positive presentation that he comes cioser to the way in which King. quoted above, defines spirituality. Feminist writers are more likely to see spirituality as a relationship with nature and the cosmos. expressed in this world; I would like to amplify King 's definition by reference to a book about children's spirituality. The Spirit of the Child. by David Hay and Rebecca Nye (1998), in which spirituality is seen as an awareness transcending but not undervaluing the material world-indeed, recognising within it a connectedness with humanity, so that 'any damage to reality is damage to oneself' (cf. Hay \& Nye 1998. p. 18). Consequent upon this realisation is a care for other people and for the environment, and for the 'nameless mystery of our existence' (Karl Rahner in Hay and Nye, 1998). It is worth looking. therefore, at the way in which Lewis's work provides what might be termed a sacramental or incarnational view in its display of the relationship between the physical and the spiritual. his suggestion of connectedness between human beings and nature in general which gives his novels something of what might today be termed an ecological perspective, and the extent to which he creates a sense of awe and presence, or 'nameless mystery'.

\section{Metonym and sacrament}

John Stephens quotes Jill Paton Walsh's association of fantasy with 'a metaphorical frame of mind' (1992, p.272). while David Lodge, himself a writer of 'realistic' novels. suggests that 'realistic fiction relies principally upon symbolism...in which the primary signified is introduced into the discourse according to the metonymic principle of spatial or temporal contiguity with what has come before' (1981,p.23). Given that Narnia is presented as a fantasy world, it might be expected that the metaphoric rather than the metonymic mode would prevail in Lewis's novels. If this were the case. it would accord with the many critics who have read them as allegory, a genre which by its nature tends to make use of the physical world as a symbol of other meanings. but which lacks true 'reality" in itself. This could be seen as chiming in with Lewis's avowed and explicit use of Plato, whose theory of forms, by suggesting that the real is located elsewhere than the place where we perceive its shadow, would seem to devalue the here and now in the exaltation of the 'other', an attitude which I have challenged above. I would claim rather that the predominant mode in the Narnia books is generally metonymic rather than metaphoric. Lewis's intense appreciation of the things of this world prevented him from indulging in the allegorical writing of, for instance, Bunyan's Pilgrim's Progress (1678) or Spenser's Faerie Queene (1590 - 1596), with which as a scholar of Renaissance literature he was very familiar. Schakel $(1979$, p.6), linking the patterns in Lewis's Narnia books with the symbols associated with the seasonal cycle by Northrop Frye. suggests that Lewis's practice is archetypal rather than allegorical. I would suggest that Lewis's use of such signifiers as food and nature displays a sacramental, incarnational atttitude which emphasises the 'reality' of both terms, signifier and signified.

As Lynne Vallone discusses in her contribution to this volume. Lewis's healthy' interest in food hardly needs stressing: from Lucy's tea with Mr Tumnus in The Lion, the Witch and the Wardrobe (1959a, p.19) to the lavish banquet set out on Aslan's table in The Voyage of the Dawn Treader (1965a, p. 163), healthy appetising food is used throughout the Narnia books as a metonym not only of spiritual goodness but also of the perfection of the essential quality of food - 'bread of heaven' perhaps. Lewis thought so highly of the significance of food that in Mere Christianity (1952), his popular statement of Christian belief, in a description which is both metaphysical and eucharistic, he terms God the food our spirits were designed to feed on' (p. 50). This imagery is not so much a devaluing of earthly food so much as an exaltation of it.

In a passage from The Last Battle, Lewis uses earthly food as a kind of 'Platonic form' for the real food of heaven, yet at the same time evokes the food's essential physical qualities. The children and King Tirian have suddenly all arrived in what from the outside seems to be a small stable building; nevertheless they find themselves in the open air, with 'deep blue sky' and a grove of fruit trees, which they begin to eat: 
What was the fruit like? Unfortunately no one can describe a taste. All that / cansay is that, compared with those fruits, the freshest grape-fruit you've ever eaten was dull, and the juiciest orange was $d r y$, and the most melting pear was hard and woody, and the sweetest wild strawberry was sour.

(1964, p.125)

That enjoying the taste of the fruit depends on what the recipient brings to the experience is apparent from the fact that later in the same chapter. the dwarfs who are presented by Aslan with a delicious banquet ("pies and tongues and pigeons and trifles and ices') perceive it as 'a bit of old turnip and... a raw cabbage leaf'. At one level. Lewis would appear to be alluding to the inability of unbelievers to derive spiritual profit from receiving Holy Communion; in the words of Paul, they are 'not discerning the Lord's body' (I Cor. 11:29). At the same time, in a mode which recalls for instance George Herbert (e.g. in 'Love III'), he is using the earthly feast to prefigure the heavenly one, something which can only be done by negatives (compare the way in which most of the terms used to describe God and eternity, such as 'infinite', 'endless'. 'immortal', work by denying the limitations of earthliness). The structural pairings and contrasts create a semiotic in which the mode is associative rather than metaphorical-the heavenly fruit is compared to earthly fruit, rather than either of them being seen simply as figures for God's love or the bliss of heaven.

Whether or not Lewis is thought to devalue the taste of the grape-fruit, orange, pear and strawberry by first building up in the hearer the appreciation of their delights and then reversing it with negative terms such as 'dull', 'dry' and 'sour'. must remain subjective to each reader. He is relying on the reader's experience of both freshness and dullness: we are forced to recall not only the positive experience of something being de!icious, but the unreliability and inconsistency of earthly experience. One day we might eat 'the sweetest wild strawberry' but on another we might encounter one which was sour. Lewis is at the same time using a kind of proportionality - as inferior food is to good earthly food, so good earthly food is to heavenly food-and reminding us of the fact that not all earthly food is equally delicious. Nevertheless, the recognition of the validity of the earthly experience is essential for the comparison to work - not devaluing the earthly and human but seeing it as a sign prefiguring the heavenly.

\section{Connectedness}

The very nature of Narnia is one of interconnectedness between the human, the animal and the vegetable worlds. Although not all animals are talking animals, the majority of those we encounter in the books are endowed with as much language and understanding as the human characters. It could be argued that this is no more than we glimpse in countless anthropomorphic children's novels and picture books in which the animal characters interact with others of different species and with humans, from Alice in Wonderland (1865) through The Wind in the Willows (1908) and Winnie the Pooh (1926) to. for instance, Anthony Browne's Willie the Wimp (1984). The difference lies in the perspective. While the behaviour of the animal characters in most children's fiction tends to bears more resemblance to that of humans than of 'real' animals, it is frequently nearer that of children than of adults. In most of these books too, with the exception of Alice in Wonderland, the 'point of view' is generally that of the animal characters. Lewis's animals, however, are seen through the children's eyes, and their human characteristics include moral responsibility. Most of them. like Mr Tumnus and Reepicheep, are adults. They are portrayed as being just as valuable as humans and our response to them is the opposite of that of Uncle Andrew, in The Magician's Nephew, whose nature has been distorted by years of ill-treatment of animals:

He had never liked animals at the best of times, being usually rather afraid of them; and of course years of doing cruel experiments on animals had made him hate and fear them far more.

(1963, p.119)

As a resuit, he is completely unable to recognise the way in which the talking animals communicate: All he saw... was a lot of dangerous wild animals walking vaguely about'

(1963. p.116)

This connectedness between humans and nature extends further, as we see when the nymph of a beech tree pleads to Tirian in the last book: 
'Justice, Lord King!' she cried. 'Come to our aid. Protect your people. They are felling us in Lantern Waste. Forty great trunks of my brothers and sisters are already on the ground. '

(1964, p.21)

The trees are just as much subjects of the king as are the humans and the talking animals.

Manlove (1987, p. 140) comments on the way in which Lewis creates a sense of Narnia as a 'solid' reality. The scenes which do this most effectively tend also to be those which show Lewis's regard for nature most vividly: the descriptions of creation in The Magician's Nephew and of the coming of spring in The Lion, the Witch and the Wardrobe. A quotation from the latter may help to make the point: it is seen through the eyes of Edmund, who at this point is a thrall to the White Witch:

He noticed a dozen crocuses growing round the foot of an old tree-gold and purple and white. Then came a sound even more delicious than the sound of the water. Close beside the path they were following a bird suddenly chirped from the branch of a tree. It was answered by the chuckle of another bird a little further off. And then, as if that had been a signal, there was chattering and chirruping, in every direction, and then a moment of full song, and within five minutes the whole wood was ringing with birds' music, and wherever Edmund's eyes turned he saw birds alighting on branches or sailing overhead or chasing one another or having their little quarrels or tidying up their feathers with their beaks... The sky became bluer and bluer, and now there were white clouds hurrying across it from time to time. In the wide glades there were primroses. A light breeze sprang up which scattered drops of moisture from the swaying branches and carried cool. delicious scents against the faces of the travellers. The trees began to come fully alive. The larches and birches were covered with green, the laburnums with gold. Soon the beech trees had put forth their delicate transparent leaves...

'This is no thaw, 'said the dwarf, suddenly stopping. 'This is Spring'

(1959a, pp.110-112)
I have quoted this passage at some length because I feel it exemplifies the way in which Lewis uses language to affirm nature. Firstly, the fact that it is seen through Edmund's eyes reveals to us that unlike, for instance, Uncle Andrew's, his personality possesses a latent goodness which enables him to respond positively to the beauty around him. We are frequently reminded that we are looking at it with Edmund, where a passage of plain description would be likely to lose the interest of young readers, the interest being intensified by the use of details such as the 'little quarrels' of the birds. The scene is far from static, but is constantly changing, filled with motion and sound, and with appeal to the senses of smell and touch. Several patterns interweave with each other: the cluster of words which remind us of Edmund's seeing ('noticed', 'eyes') are interspersed with those which emphasise sound: the 'sounds', repeated, of the water; the 'ringing' of the 'birds' music', as well as the description of their distinctive melodies with an underlying onomatopoeia, notable in the repetition of the 'ch' sounds, so that the bird song, introduced by the initial 'chirp' and 'chuckle', and maintained in the 'chattering and chirruping', is actually to be heard later in the 'larches and birches' and the 'beeches'. As with the images of food mentioned earlier, the cumulative effect is one of association, of contiguity, building up a sense of solidity of essence. The colours are vivid throughout, though the description conveys delicacy rather than glare. Smaller patterned sequences occur, culminating in the alliteration of the ' $s$ ' sounds in the dwarf's recognition, despite himself, that this is Spring. All this is achieved with a deceptive facility in the writing, which anyone who has tried to emulate Lewis's lucidity and ease will know is in fact very difficult.

Among several other aspects which are notable here is the effect created by the images of water. Prior to this, water has been locked up in ice and snow, but here we hear its sound, and feel 'the drops of moisture from the swaying branches.' Within the Christianised imagination of Lewis, the sacramentality of these images is evident, with its association not only with the coming of Spring, as recognised by the dwarf, but also with Baptism, the sacrament of initiation into the spiritual life. 


\begin{abstract}
A Sense of Presence
For Lewis, as for many people who have displayed intense appreciation of nature, from Wordsworth to Kenneth Grahame, nature is never empty. By contrast the evil associated with the White Witch is, as pointed out by Patterson (1991, pp.11-12) sterile and empty. Aslan is always immanent in the world of Narnia, whether he is visible or not, as we realise when Lucy's use of the spell of making things visible has the same effect on the great lion as on the Dufflepuds:
\end{abstract}

'Oh, Aslan, 'said she, 'it was kind of you to come.' 'I have been here all the time, 'said he, 'but you have just made me visible.'

(1965a, p.136)

It could perhaps be claimed that Lewis delimits this mysterious presence too precisely in the person of Aslan himself, failing to do justice to the mystery of nature, just as Kenneth Grahame had only limited success in putting his own feelings into concrete form in the character of Pan in the chapter 'The Piper at the Gates of Dawn' in The W'ind in the Willows. Lewis is probably more successful when he confines himself to showing Narnia as a living landscape, and the passage I have quoted above is one of many instances where this is done very evocatively. The same. I think, applies in this passage from near the end of The Voyage of the Dawn Treader:

What they [Edmund, Lucy and Eustace] saweastward, beyond the sun- was a range of mountains. It was so high that either they never saw the top of it or they forgot it. None of them remembers seeing any sky in that direction. And the mountains must really have been outside the world. For any mountains even a quarter or a twentieth of that height ought to have hadice and snow on them. But these were warm and green and full of forests and water falls however high you looked. And suddenly there came a breeze from the east, tossing the top of the wave into foamy shapes and ruffling the smooth water all round them. It lasted only a second or so but what it brought them in that second none of those three children will ever forget. It brought both a smell and a sound, a musical sound. Edmund and Eustace would never talk about it afterwards.
Lucy could only say, 'It would break your heart.'

'Why, ' said I. 'was it so sad?' 'Sad!! No, 'said Lucy.

(The Voyage of the Dawn Treader, p.206)

It seems to me that in this passage, and others like it, Lewis is making accessible to the young reader the awe, 'mysterium tremendens', that Rudolf Otto claims as a feature of the numinous; Otto suggests that people experiencing this seem to have a strong impression of being dependent creatures, feeling awe at something or someone greater than themselves which they sense as wholly other, yet fascinating (1926, p.xvii). Hay and Nye (1998, especially ch.3) provide evidence that children are often implicitly aware of a spiritual dimension to experience. In the above passage, the mountains of Lewis's own childhood have been multiplied in height, clothed in even more beautiful vegetation than he would have glimpsed, and associated with feelings which, though beyond expression, can be evoked by the senses rather than limited by words. It is interesting to note the overt narratorial ' $I$ ' in the final sentence. a feature which makes the narrator present as a character who has actually met Lucy, something which may be intended to give conviction to the young reader, but which also provides for those familiar with Lewis's own writings about beauty and joy, a touching link with his own experience.

\section{CONCLUSION}

I have no wish to deny the existence of unsatisfactory features of the Narnia books, nor to join a chorus of uncritical adulation of Lewis. Most of the negative aspects of his work, however, result from the fact that the books were written by an upper middle-class male, educated at public school and the old universities, and spending all his professional life in a largely masculine academic environment, which at that time was even more male dominated than it is today. During the period in which he lived, there was little recognition of the need to recognise how bias can result from unthinking acceptance of language and culture which devalues or ignores females and those from different backgrounds. His belligerence and his negative views about what he sees as the wrong kind of femininity are inescapable, but those critics who charge him with lacking a proper appreciation of the 
splendours and delights of this world seem to have missed many of the qualities he exhibits, particularly in descriptions. I find his writing often has a luminous quality, clear and lucid, making the beauties of nature very' attraclive. especially to the child reader (perhaps to a greater extent than is achieved by Tolkien). It may be that his appeal is greater for those whose own spiritual experience resonates with that he portrays Lucy as having in her relationship with Aslan.

Some readers who do not share Lewis`s Christian beliefs have projected on to him a degree of intolerance of other beliefs of which there is little evidence, in the Narnia books or elsewhere. In fact . as he says in Mere Christianity, If you are a Christian you do not have to believe that all the other religions are simply wrong... you are free to think that all these religions... contain at least some hint of the truth' (p.39). This conviction is spelt out in The Last Battle, where the Calormene Emeth learns that in his disinterested service of the false God Tash he has really been following Asian-in a much better way in fact than some who claim to be true followers of Aslan (1964. p.149). At the same time, Lewis makes an effective critique of the wrong kind of Christianity: early in the same book the ape, Shift, who purports to be an intermediary of Aslan, seems to be a skewed portrait of those Christians. of all denominations, who feel that they have a monopoly of the right kind of access to God ( 1964. p. 31 ). The wrong kind of actions supposedly performed in the service of the true God are atso eschewed: 'If any man do a cruelty in my name, then. though he says the name Aslan, it is Tash whom he serves' (1964, p.149). The hope of salvation is in fact held out to all who long for it. even if they have no notion of what they are seeking: as Aslan says to Emeth: 'Unless thy' desire had been for me thou wouldst not have sought so long and so truly` (1964. p.149).

I would claim then that Lewis does value the things of this earth and has made a good case for their quality - after all. shadows must have enough resemblance to the objects which cast the shadows for them to be recognisable. To helieve that Aslan's country is worth yearning for, it is necessary to have enjoyed the earthly Narnia, and I would suggest that the fact that more than fifty years on. children are still doing this, implies that Lewis was not so wrapped up in visions of heaven as to deny the value of this world.

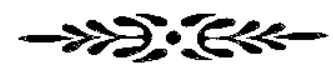

\section{REFERENCES}

Clack. B. (1998) 'Virgins and vessels: feminist reflections on dominant models of spirituality' in M. Hayes, W. Porter, \& D. Tombs, (eds) Religion and Sexuality. Sheffield. Academic Press.

Fort. M. (1999) 'Harry's game' [an interview with I.K. Rowling], in The Guardian Weekend, June 26.

Frye, N. (1951) 'The archetypes of literature', in D. Lodge (ed) (1983) Twentieth Century Literary Criticism. Harlow, Longman.

Hay, D. \& Nye, R. (1998) The Spirit of the Child. London, HarperCollins.

Holbrook, D. (1973) 'The problem of C.S. Lewis', in G. Fox et al. (eds) (1976) Writers, Critics and Children. London, Heinemann. from Children's Literature in Education 10 March.

Hooper, W. (1974) 'Narnia: the author, the critics, and the tale', Children's Literature 3: 12-22.

King, U. (1989) Women and Spirituality. Basingstoke, Macmillan.

Lewis. C.S. (1945) The Great Divorce. London, Geoffrey Bies.

Lewis, C.S. (1965c) [1954] The Horse and his Boy. Harmondsworth, Penguin.

Lewis, C.S. (1964) [1956] The Last Battle. Harmondsworth, Penguin

Lewis. C.S. (1959a) [1950] The Lion, the Witch and the Wardrobe. Harmondsworth. Penguin. 
Lewis, C.S. (1963) [1955] The Magician's Nephew. Harmondsworth, Penguin.

Lewis, C.S. (1952) Mere Christianity. London, Collins

Lewis, C.S. (1962) [1951] Prince Caspian. Harmondsworth, Penguin.

Lewis. C.S. (1965b) [1953] The Silver Chair. Harmondsworth, Penguin.

Lewis, C.S. (1959b) [1955] Surprised by Joy. London. Collins.

Lewis. C.S. (1965a) [1952] The Voyage of the Dawn Treader. Harmondsworth, Penguin.

Lodge. D. (1981) Working with Structuralism. London, Routledge.

Manlove, C. N. (1987) C.S Lewis: His Literary Achievement. Basingstoke: Macmillan.

Otto, R. (1926) The Idea of the Holy. $4^{\text {th }}$ edition. Oxford. University Press.

Patterson. N. (1991) 'Always winter and never Christmas', Mythlore 67:10-14.

Paul, L. (1998) Reading Otherways. Stroud, Thimble Press.

Schakel, P. (1979) Reading with the Heart: The Way into Narnia. Grand Rapids, Michigan, Eerdmans.

Schakel, P.J. \& Huttar, C.A. (eds) (1991) Word and Story in C.S. Lewis. Missouri. University Press.

Stephens. I. (1992) Language and ldeology in Children's Fiction. Harlow. Longman.

Sudbrack, J. (1975) 'Spirituality', in K. Rahner, (ed) Encyclopedia of Theology. London, Burns \& Oates.

Wagner, E. (2000) 'Divinely inspired' [an interview with Philip Pullman], in The Times. Oct 18

\section{BIOGRAPHICAL NOTE}

Pat Pinsent has worked at the University of Surrey Roehampton for many years, and is now a Senior Research Fellow in English. Since she officially 'retired', she has produced material for the Distance Learning mode of the MA in Children's Literature, as well as tutoring students on this course and other research degrees at Roehampton. She has also devised a Distance Learning course on contemporary children's literature for students who do not have the qualifications to take the MA. Her books include The Power of the Page (1993) and Children's Literature and the Politics of Equality (1997). She has edited two collections based on IBBY/ National Centre for Research in Children's Literature conferences, $P o p$ Fictions (1999) and The Big Issues (2001), and is also current editor of the British IBBY journal, IBBYLink. As well as children's literature, her articles and conference papers include several on seventeenth-century English poetry

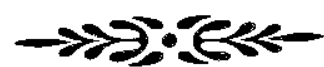

